\title{
Research on Evaluation of Innovation and Entrepreneurship Ability of Applied College Students
}

\author{
Juan Li, Wei Pan \\ Wuhan Institute of Business and Technology, China
}

Keywords: applied universities; innovation and entrepreneurship; evaluation index system; AHP.

\begin{abstract}
Based on the actual situation of applied undergraduate colleges and the rules of education, this paper constructs an evaluation index system for college students' innovation and entrepreneurship from four aspects: innovation and entrepreneurship character, innovation and entrepreneurship awareness, innovation and entrepreneurship support and innovation and entrepreneurship practice. The analytic hierarchy process was used to calculate the weights of the indicators at all levels, and the evaluation results were analyzed, in order to improve the innovation ability of college students and the entrepreneurial ability based on innovation, and promote the reform of the application-oriented talent training model.
\end{abstract}

\section{Introduction}

Under the environment of mass entrepreneurship and innovation, we will change the concept of employment and promote employment through entrepreneurship to promote the comprehensive development of the city's economy. Entrepreneurship as a new way of employment for college students is also an important factor in measuring the level of applied education for college graduates. Local undergraduate colleges need to change from research-oriented to application-oriented because of their target orientation, training programs, teacher strength, and quality of students. The goal of talent training is also changed from the cultivation of research talents to the cultivation of applied talents. Innovation and entrepreneurship are an important part of applied talent. However, because innovation and entrepreneurship education started late in China, the innovation and entrepreneurship education of Chinese college students is still in the process of exploration and exploration. Therefore, the article evaluates the innovation and entrepreneurship ability of college students in applied colleges. Based on the theoretical research on the ability of innovation and entrepreneurship, the paper aims to measure the innovation and entrepreneurship ability of college students by applying the index system, improve the level of teachers' innovation and entrepreneurship, and improve students' innovation. Entrepreneurial skills, improve the training model of innovative and entrepreneurial talents.

\section{The construction of evaluation index system for college students' innovation and entrepreneurship ability}

The establishment of an evaluation system for the innovation and entrepreneurship of college students in applied universities should adhere to the principles of combining science, feasibility, qualitative and quantitative, dynamic and market-oriented. Through reviewing a large amount of literature and surveys, this study believes that the evaluation of college students' innovation and entrepreneurship ability is mainly reflected by the four dimensions of innovation and entrepreneurship, innovation and entrepreneurship, innovation and entrepreneurship support and innovation and entrepreneurship practice.

The evaluation index system of application-oriented college students' innovation and entrepreneurship ability is: innovation and entrepreneurship character B1 (innovation entrepreneurship courage $\mathrm{C} 1$, innovation entrepreneurship quality $\mathrm{C} 2$, social ability $\mathrm{C} 3$, social responsibility C4); innovation entrepreneurship awareness B2 (innovation entrepreneurship 
knowledge learning C5, innovation entrepreneurship concept C6, innovative entrepreneurial motivation C7); innovation and entrepreneurship support B3 (funding support C8, policy support C9, school support C10, support of parents and friends C11); innovation entrepreneurship practice B4 (innovative entrepreneurship simulation practice C12, innovative entrepreneurial society Practice C13, innovation and entrepreneurship practice results C14).

\section{Evaluation of the Innovation and Entrepreneurship Ability of Applied College Students Based on Analytic Hierarchy Process}

The Analytic Hierarchy Process (AHP) is a multi-criteria decision-making method that combines qualitative and quantitative methods proposed by the famous American operations researcher TLSatty et al. in the 1970s. It refers to a decision-making method that decomposes related elements of decision-making problems into levels such as target layer, criterion layer, and program layer, and then performs quantitative and qualitative analysis on this basis. The specific process of weight determination is described below.

\subsection{Construct a comparison matrix.}

According to the evaluation index system, each indicator belonging to the same indicator is compared with each other to determine the relative importance of each indicator to form a judgment matrix. The 1-9 scale method is adopted, and the specific meanings are as follows:

Table 1 Judgment matrix 1-9 scale and meaning

\begin{tabular}{|c|l|}
\hline Scaling & \\
\hline 1 & Expressing the same importance compared to two factors \\
\hline 3 & One factor is slightly more important than the other because of two factors \\
\hline 5 & $\begin{array}{l}\text { One factor is significantly more important than the other because of two } \\
\text { factors }\end{array}$ \\
\hline 7 & One factor is stronger than the other because of two factors \\
\hline 9 & One factor is more important than the other because of two factors \\
\hline 6,8 & Median value of the above two adjacent judgments \\
\hline reciprocal & $\begin{array}{l}\text { Median value of the above two adjacent judgments } \\
\text { Comparative judgment } b_{j i}=1 / b_{i j}\end{array}$ \\
\hline
\end{tabular}

Before determining the comparison matrix, it is necessary to sort the importance degree of each sub-indicator belonging to the same index to avoid contradiction, but the subjectivity of the process of sorting and determining the importance degree value is relatively strong, so the article analyzes a large amount of relevant literature materials, and According to the opinions and suggestions of some experts, the order of importance and the scale value of each indicator are finally determined. The comparison matrix values for each indicator are as follows:

Table 1 AB first-level indicator comparison matrix

\begin{tabular}{|c|c|c|c|c|}
\hline A & B1 & B2 & B3 & B4 \\
\hline B1 & 1.00 & 0.50 & 2.00 & 3.00 \\
\hline B2 & 2.00 & 1.00 & 3.00 & 4.00 \\
\hline B3 & 0.50 & 0.33 & 1.00 & 2.00 \\
\hline B4 & 0.33 & 0.25 & 0.50 & 1.00 \\
\hline
\end{tabular}


Table 2 B1-C secondary indicator comparison matrix

\begin{tabular}{|c|c|c|c|c|}
\hline B1 & C1 & C2 & C3 & C4 \\
\hline C1 & 1.00 & 1.00 & 2.00 & 3.00 \\
\hline C2 & 1.00 & 1.00 & 3.00 & 4.00 \\
\hline C3 & 0.50 & 0.33 & 1.00 & 2.00 \\
\hline C4 & 0.33 & 0.25 & 0.50 & 1.00 \\
\hline
\end{tabular}

Table 3 B2-C secondary indicator comparison matrix

\begin{tabular}{|c|c|c|c|}
\hline B2 & C5 & C6 & C7 \\
\hline C5 & 1.00 & 2.00 & 0.33 \\
\hline C6 & 0.50 & 1.00 & 0.20 \\
\hline C7 & 3.00 & 5.00 & 1.00 \\
\hline
\end{tabular}

Table 4 B3-C secondary indicator comparison matrix

\begin{tabular}{|c|c|c|c|c|}
\hline B3 & C8 & C9 & C10 & C11 \\
\hline C8 & 1.00 & 3.00 & 5.00 & 2.00 \\
\hline C9 & 0.33 & 1.00 & 2.00 & 0.50 \\
\hline C10 & 0.20 & 0.50 & 1.00 & 0.33 \\
\hline C11 & 0.50 & 2.00 & 3.00 & 1.00 \\
\hline
\end{tabular}

Table 5 B4-C secondary indicator comparison matrix

\begin{tabular}{|c|c|c|c|}
\hline $\mathrm{B} 4$ & $\mathrm{C} 12$ & $\mathrm{C} 13$ & $\mathrm{C} 14$ \\
\hline $\mathrm{C} 12$ & 1.00 & 2.00 & 5.00 \\
\hline $\mathrm{C} 13$ & 0.50 & 1.00 & 2.00 \\
\hline $\mathrm{C} 14$ & 0.20 & 0.50 & 1.00 \\
\hline
\end{tabular}

\subsection{Hierarchical single sorting and consistency check.}

The article uses the square root method to find the weight, the specific steps are as follows:

First calculate the product of each row of the comparison matrix $M_{i}=I_{j=1}^{n} \partial_{i j}(i=1,2,3 \cdots n)$

Then calculate the product of each row $M_{i}$ of $n$ Secondary root $\bar{w}_{i}=\sqrt[n]{M_{i}}$

Pair vector $\bar{w}=\left(\bar{w}_{1}, \bar{w}_{2}, \ldots, \bar{w}_{n},\right)$ Normalized processing $w_{i}=\bar{w}_{i} / \sum_{i=1}^{n} \bar{w}_{i}(i=1,2,3 \cdots n), \quad w_{\mathrm{i}}$ It is the weight of the relative importance of each indicator.

In order to ensure the reliability and consistency of the judgment matrix, it is necessary to pass the consistency test. by $A w^{T}=\lambda w^{T}$ Find the maximum eigenvalue of the judgment matrix $\lambda_{\max }=\frac{1}{n} \sum_{i=1}^{n} \frac{\left(A w^{T}\right)_{i}}{w_{i}}$ And then ask $C I$ with $C R$ Value. $C I, C R$ Is the consistency check correlation number, $C I$ Indicates consistency indicators, $C R$ Indicates the random consistency ratio.

Among them: $C I=\frac{\lambda_{\max }-n}{n-1}, \quad C R=\frac{C I}{R I}$

When $C R<0.10$ At the same time, the results are considered to have satisfactory consistency; otherwise, the values of the elements of the judgment matrix need to be re-adjusted until satisfactory. $R I$ It is a random consistency indicator, and its value is as follows: 
Table 6 Value of RI

\begin{tabular}{|c|c|c|c|c|c|c|c|c|c|c|}
\hline $\begin{array}{c}\text { Judging matrix } \\
\text { order } n\end{array}$ & 1 & 2 & 3 & 4 & 5 & 6 & 7 & 8 & 9 & 10 \\
\hline$R I$ & 0.00 & 0.00 & 0.58 & 0.90 & 1.12 & 1.24 & 1.34 & 1.41 & 1.45 & 1.49 \\
\hline
\end{tabular}

According to the above steps, you can calculate:

The weight of the first-level indicator $=(0.28,0.47,0.16,0.10), \lambda=4.03, \mathrm{CR}=0.01$, passed the consistency test; the weight of the innovative entrepreneurial character index $=(0.34,0.40,0.16$, $0.10), \lambda=4.03, \mathrm{CR}=0.01$, through the consistency test; innovation entrepreneurial awareness index weight $=(0.23,0.12,0.65), \lambda=3, \mathrm{CR}=0$, through the consistency test; innovation entrepreneurial knowledge index weight $=(0.48,0.16,0.09,0.27), \lambda=4.01, \mathrm{CR}=0$, passed the consistency test; innovation entrepreneurial practice index weight $=(0.60,0.28,0.13), \lambda=3, \mathrm{CR}=0$, passed the consistency test.

\subsection{Level total ordering.}

The weight that calculates the relative importance of each factor of a certain level relative to all factors of the previous level is called the total order of the hierarchy. That is to calculate the importance of each factor of a certain level relative to the target layer. This process is carried out layer by layer from the highest level to the lowest level.

Table 7 Level total ordering

\begin{tabular}{|c|c|c|c|c|c|c|}
\hline $\begin{array}{c}\text { Floor } \\
\text { Time } \\
\text { S }\end{array}$ & 0.28 & 0.47 & 0.16 & 0.10 & $\begin{array}{c}\text { Total level } \\
\text { Sort weight }\end{array}$ & $\begin{array}{c}\text { Heavy } \\
\text { indicators } \\
\text { Sexual ordering }\end{array}$ \\
\cline { 2 - 5 } C1 & 0.34 & 0 & 0 & 0 & 0.09 & 3 \\
\hline C2 & 0.40 & 0 & 0 & 0 & 0.11 & 2 \\
\hline C3 & 0.16 & 0 & 0 & 0 & 0.05 & 6 \\
\hline C4 & 0.10 & 0 & 0 & 0 & 0.03 & 8 \\
\hline C5 & 0 & 0.23 & 0 & 0 & 0.11 & 2 \\
\hline C6 & 0 & 0.12 & 0 & 0 & 0.06 & 5 \\
\hline C7 & 0 & 0.65 & 0 & 0 & 0.31 & 1 \\
\hline C8 & 0 & 0 & 0.48 & 0 & 0.08 & 4 \\
\hline C9 & 0 & 0 & 0.16 & 0 & 0.03 & 8 \\
\hline C10 & 0 & 0 & 0.09 & 0 & 0.01 & 9 \\
\hline C11 & 0 & 0 & 0.27 & 0 & 0.04 & 7 \\
\hline C12 & 0 & 0 & 0 & 0.60 & 0.06 & 5 \\
\hline C13 & 0 & 0 & 0 & 0.28 & 0.03 & 8 \\
\hline C14 & 0 & 0 & 0 & 0.13 & 0.01 & 9 \\
\hline
\end{tabular}

\section{The evaluation results analysis}

Through the overall ranking of the hierarchy, it can be seen that the motivation for innovation and entrepreneurship ranks first. This shows that the beginning of any innovation and entrepreneurial activity is due to the motivation of innovation and entrepreneurship. The motivation of college students to innovate and start their business comes from the demand of personal wealth, improve the quality of life, and get the public. The recognition and realization of self-worth and other aspects; secondly, the innovation and entrepreneurial knowledge learning and the quality of innovation and entrepreneurship, indicating that the application-oriented college students must have rich basic knowledge and good entrepreneurial quality in order to have the ability to innovate; This shows that college students need a certain amount of courage to engage in innovative activities, encounter difficulties, a strong will, not afraid of setbacks, and have a spirit of active struggle. The order of importance of other indicators is, in turn, funding support, innovative entrepreneurial ideas and 
innovative entrepreneurial simulation practices, social skills, social responsibility and policy support, social practices, parent and friend support, and innovative entrepreneurial practices, research findings and interviews with students. The conclusions obtained at the time are basically the same.

Of course, with the changes of the times, the evaluation indicators of college students' innovation and entrepreneurship will also change accordingly. Each applied university should make appropriate adjustments to the evaluation indicators or weights according to its actual situation, only through continuous adjustment. And rich, in order to make the evaluation process of college students' innovation and entrepreneurship ability more standardized and scientific, so as to better enhance college students' ability of innovation and entrepreneurship.

\section{Acknowledgement}

Fund Project: This paper is the research result of the Wuhan University Business School-level project "Research on the Incentive Mechanism of Innovation and Entrepreneurship of Applied Undergraduate College Students" (Project No.: A2016003); this paper is the research result of "Study on Incentive Mechanism of College Students' Innovation and Entrepreneurship" (Project No. ST201722) of Wuhan University of Technology College Students' Science and Technology Innovation Training Program.

\section{References}

[1] Yuanyuan Sun. Legal Risks and Social for University Students' Innovative Undertaking [A]. Singapore Management and Sports Science Institute, Singapore, Hong Kong Education Society, Hong Kong. Proceedings of 2017 4th International Conference on Economic, Business Management and Education Innovation (EBMEI 2017)[C].Singapore Management and Sports Science Institute, Singapore, Hong Kong Education Society, Hong Kong:,2017:5.

[2] Lisbeth Brøde Jepsen, Claudio Dell'Era, Roberto Verganti. The contributions of interpreters to the development of radical innovations of meanings: the role of 'Pioneering Projects' in the sustainable buildings industry [J]. R\&amp; D Management, 2014, 44(1).

[3] Yu Xiong. The Problems in College \&amp; University Students' Innovative Undertaking Education and Research [A]. Singapore Management and Sports Science Institute, Singapore. Proceedings of 2015 SSR International Conference on Social Sciences and Information(SSR-SSI 2015 V11 ) [C].Singapore Management and Sports Science Institute,Singapore:,2015:5.

[4] Denis G. Arnold, Jennifer L. Troyer. Does Increased Spending on Pharmaceutical Marketing Inhibit Pioneering Innovation?[J]. Journal of Health Politics, Policy and Law, 2016, 41(2). 